\title{
Heart Valve Replacements with Regenerative Capacity
}

\author{
Petra E. Dijkman ${ }^{a}$ Emanuela S. Fioretta ${ }^{a}$ Laura Frese $^{a} \quad$ Francesco S. Pasqualini $^{a}$ \\ Simon P. Hoerstrup ${ }^{a, b, c}$ \\ a Institute for Regenerative Medicine (IREM), University of Zurich, Zurich, Switzerland; \\ ${ }^{b}$ Department of Biomedical Engineering, Eindhoven University of Technology, Eindhoven, The Netherlands; \\ ${ }^{c}$ Wyss Translational Center Zurich, University of Zurich and ETH Zurich, Zurich, Switzerland
}

\section{Keywords}

Heart valves - Heart valve prosthesis .

Tissue engineering - Transcatheter aortic valve replacement - Scaffolds - Regenerative medicine . Decellularized tissues · Biomaterials

\section{Summary}

The incidence of severe valvular dysfunctions (e.g., stenosis and insufficiency) is increasing, leading to over 300,000 valves implanted worldwide yearly. Clinically used heart valve replacements lack the capacity to grow, inherently requiring repetitive and high-risk surgical interventions during childhood. The aim of this review is to present how different tissue engineering strategies can overcome these limitations, providing innovative valve replacements that proved to be able to integrate and remodel in pre-clinical experiments and to have promising results in clinical studies. Upon description of the different types of heart valve tissue engineering (e.g., in vitro, in situ, in vivo, and the pre-seeding approach) we focus on the clinical translation of this technology. In particular, we will deepen the many technical, clinical, and regulatory aspects that need to be solved to endure the clinical adaptation and the commercialization of these promising regenerative valves.

(C) 2016 S. Karger GmbH, Freiburg

Petra E. Dijkman and Emanuela S. Fioretta have contributed equally to the manuscript.

\section{Introduction}

Aging, rheumatic heart diseases, and the growing prevalence of heart and vascular system conditions increased the incidence of severe valvular dysfunctions (e.g., stenosis and insufficiency) that require surgically implanted valve replacements. With over 300,000 valves implanted worldwide yearly, the global prosthetic heart valve market comprising mechanical and bioprosthetic replacements [1] is expanding [2]. Due to their durability, the mechanical valves are the gold standard treatment for patients up to 60 years, even though the life-long anticoagulant treatment required to prevent thrombosis [3] reduces the patient's quality of life [4]. Bioprosthetic valves based on glutaraldehyde-fixed xenogeneic (e.g. bovine pericardium or porcine valves) or allogeneic (e.g. from human donor) materials that preserve the native-like geometry and structure mitigate the need for anticoagulants by ensuring a more physiological hemodynamic profile.

The standard surgical procedure to replace the valve is highly invasive and uses a cardiopulmonary bypass machine to provide the extracorporeal circulation and ventilation for the patient. Despite the good perioperative and long-term results, this procedure cannot be performed on patients with more comorbidities [5]. In addition, prosthesis-associated complications (e.g., thromboembolism, infection, bioprosthetic valve degeneration and calcification, mechanical valve failure) have still considerable impact on patient's life [6].

A possible alternative for young patients, but suitable only for small valvular defects (e.g., small perforations or isolated spots of endocarditis), is represented by the reconstructive procedures (i.e., valve repair). The aim of valve repair is to replace the damaged area of the leaflet with a patch of autologous, or xenogeneic and glutaraldehyde-fixed, pericardium [7]. This technique has the great advantage of eliminating the complications associated with the valve

\section{KARGER \\ Fax +497614520714

\section{() 2016 S. Karger GmbH, Freiburg}

$1660-3796 / 16 / 0434-0282 \$ 39.50 / 0$
Prof. Dr. Simon P. Hoerstrup

Institute for Regenerative Medicine (IREM) University of Zurich

Moussonstrasse 13, 8044 Zurich, Switzerland simon.hoerstrup@uzh.ch 
replacement [6]. However, it is primarily used for mitral valve disease because of the enhanced complexity of performing the reconstructive surgery in the aortic environment.

To overcome the limited applicability of the valve repair and to extend the surgical valve replacement to the increasing number of patients with higher perioperative risk profile, surgeons introduced the use of catheters to implant minimally invasively the valves [8]. To be successful, this method requires the combination of a crimpable stent and a valve that can be folded into a delivery device without breaking. Considering these requirements, currently the only valves available for this approach are the bioprosthetic ones. Interestingly, the minimally invasive procedure is now considered as the treatment of choice for those frail elderly patients previously considered as inoperable because of comorbidities. The possibility of extending this technique also to a younger patient cohort is appealing but limited by the use of glutaraldehyde-fixed bioprostheses that, especially in children, undergo degenerative failure [9]. Additionally, both mechanical and bioprosthetic valves lack the capacity to remodel and grow with the patient, inherently leading to multiple surgeries to replace the valve, especially in pediatric patients, with an increasing risk of morbidity and mortality. This strengthens the need for regenerative heart valve replacements suitable for pediatric patients and for the minimally invasive implantation technique.

The aim of this review is to present how tissue engineering strategies can overcome these limitations, providing innovative valve replacements with regenerative and growth capacity (see 'Tissue Engineering Approaches for Heart Valve Replacements' below). The clinical translation of these tissue engineering approaches has been reviewed in 'Clinical Translation of Tissue-Engineered Valve Replacements' (see below), focusing not only on the clinical trials but also on the still open technical, clinical, and regulatory challenges that need to be solved to endure the clinical adaptation of these regenerative valves. Finally, a critical conclusion will summarize how these regenerative replacements will offer a lifelong solution for the increasing numbers of cardiovascular patients worldwide.

\section{Tissue Engineering Approaches for Heart Valve Replacements}

Tissue engineering has been proposed as a possible approach to fulfill the need for valve replacements able to remodel, regenerate, and grow with the patient [10].

The original in vitro heart valve tissue engineering paradigm, as defined in 1993 by Langer and Vacanti [11], comprises a 3D scaffold seeded with autologous cells and subsequent in vitro tissue formation in a bioreactor. Once the new extracellular matrix (ECM) is formed, the living construct can be implanted enabling further in vivo tissue growth and remodeling.

Since then, significant progress has been made in the development and application of bioresorbable materials for the development of a tissue-engineered heart valve (TEHV). In general, the scaffold should be biocompatible, favor cell adhesion, and have sufficient porosity, permeability and thrombus resistance. In addition, material degradation should be carefully balanced with matrix formation in order to always retain sufficient mechanical properties to sustain the cyclic loading of the heart.

Nowadays, several materials that can fulfill these specific requirements have been investigated as scaffold for TEHVs. Allogeneic and xenogeneic heart valves provide the ideal geometry for a starter scaffold; however, they required glutaraldehyde-fixation to prevent the immunological response that limits cell infiltration and remodeling potential of the replacement [12]. Decellularization of these valves favors the long-term graft durability and preserves the biomechanical properties, without impeding cell infiltration [13]. Natural-based polymers such as gelatin, collagen, and fibrin are fast degrading non-toxic materials with low mechanical properties and a non-immunogenic response. On the other hand, biodegradable synthetic polymers such as poly-glycolic acid (PGA) and polylactic acid (PLA) have tunable mechanical properties that can be suitable for the development of strong and durable valve replacements with thin and flexible leaflets. Moreover, the material can be tuned to ensure sufficient mechanical properties at the time of implantation and controlled scaffold degradation while endogenous tissue is formed over time. The large variety of possible materials and scaffold fabrication methods suitable for the development of polymeric valve replacements have been reviewed elsewhere [14-16].

By using different combinations of cells and scaffold material, researchers have developed TEHVs following the classic in vitro tissue engineering approach (see 'Technical Challenges: Cell and Scaffold Optimization' below). More recently, cell-free constructs aimed at exploiting the regenerative capability of the body to repopulate the scaffold have been introduced in a technique defined in situ tissue engineering (see 'Clinical Challenges: Beating the Gold Standard Valve Replacements' below). Other methodologies, such as the pre-seeding and the in vivo approach, are reviewed in 'Regulatory Challenges: Towards Commercialization' (see below).

\section{In vitro TEHVs}

To create in vitro TEHVs, researchers combine different biocompatible scaffolds with autologous cells capable of producing a collagen-rich ECM. A variety of cell types have been described for this scope. The most popular autologous cell sources used are the vascular-derived myofibroblasts and endothelial cells harvested from the recipient saphenous [17] or forearm [18] vein. Alternatively, cells derived from bone marrow, adipose tissue, and peripheral blood have also the potential to generate heart valves in vitro [19-23]. In contrast to vascular cells, these cell sources can be obtained without surgical intervention, thereby enabling potential adaption into in a routine clinical scenario.

Similarly, a multitude of scaffold materials, ranging from polymeric substrates to decellularized tissues, have been used for the pre-clinical evaluation of in vitro produced TEHVs (table 1). De- 
Table 1. Overview of some pre-clinical evaluations of TEHVs in large animal models

\begin{tabular}{|c|c|c|c|c|}
\hline Scaffold material & Cells & Implantation & Main results & Year \\
\hline \multicolumn{5}{|l|}{ In-vitro TEHV } \\
\hline PGA & $\begin{array}{l}\text { autologous } \\
\text { ECs and MyoFBs }\end{array}$ & $\begin{array}{l}\text { surgical replacement of one pulmonary } \\
\text { leaflet of lambs }\end{array}$ & $\begin{array}{l}11 \text { weeks follow-up } \\
\text { ECM remodeling, no stenosis nor regurgitation } \\
\text { the cells were retained upon implantation }\end{array}$ & $\begin{array}{l}1995-1996 \\
{[24,37]}\end{array}$ \\
\hline $\mathrm{PGA}+\mathrm{P} 4 \mathrm{HB}$ & $\begin{array}{l}\text { autologous } \\
\text { ECs and MyoFBs }\end{array}$ & $\begin{array}{l}\text { surgical replacement of the pulmonary } \\
\text { valve of lambs }\end{array}$ & $\begin{array}{l}20 \text { weeks follow-up } \\
\text { increased ECM and endothelialization over time } \\
\text { no stenosis, native-like mechanical properties }\end{array}$ & $\begin{array}{l}2000 \\
{[29]}\end{array}$ \\
\hline Fibrin & $\begin{array}{l}\text { autologous ECs } \\
\text { and MyoFBs }\end{array}$ & $\begin{array}{l}\text { surgical replacement of the pulmonary } \\
\text { valve of adult sheep }\end{array}$ & $\begin{array}{l}12 \text { weeks follow-up } \\
\text { tissue remodeling and endothelialization } \\
\text { contraction of the leaflet } \\
\text { insufficiency over time }\end{array}$ & $\begin{array}{l}2009 \\
{[32]}\end{array}$ \\
\hline PGA + PLA & $\begin{array}{l}\text { autologous } \\
\text { ECs and MyoFBs }\end{array}$ & $\begin{array}{l}\text { surgical replacement of the pulmonary } \\
\text { valve of lambs }\end{array}$ & $\begin{array}{l}20 \text { weeks follow-up } \\
\text { good early remodeling } \\
\text { leaflet functionality reduced with time } \\
\text { increased regurgitation over time }\end{array}$ & $\begin{array}{l}2010 \\
{[31]}\end{array}$ \\
\hline $\mathrm{PGA}+\mathrm{P} 4 \mathrm{HB}$ & $\begin{array}{l}\text { autologous } \\
\text { ECs and MyoFBs }\end{array}$ & $\begin{array}{l}\text { transcathether replacement of the } \\
\text { pulmonary valve of adult sheep }\end{array}$ & $\begin{array}{l}8 \text { weeks follow-up } \\
\text { mobile but thickened leaflets } \\
\text { endothelialization and remodeling }\end{array}$ & $\begin{array}{l}2010 \\
{[33]}\end{array}$ \\
\hline \multicolumn{5}{|l|}{ Pre-seeded TEHV } \\
\hline $\begin{array}{l}\text { Decellularized ovine } \\
\text { pulmonary valve }\end{array}$ & autologous ECs & $\begin{array}{l}\text { surgical replacement of the pulmonary } \\
\text { valve of sheep }\end{array}$ & improved endothelialization & $\begin{array}{l}2006 \\
{[82]}\end{array}$ \\
\hline $\mathrm{PGA}+\mathrm{P} 4 \mathrm{HB}$ & $\begin{array}{l}\text { autologous } \\
\text { BMC pre-seeding }\end{array}$ & $\begin{array}{l}\text { transcathether replacement of the } \\
\text { pulmonary valve of Chacma baboons }\end{array}$ & $\begin{array}{l}4 \text { weeks follow-up } \\
\text { successful implantation } \\
\text { good leaflet function } \\
\text { host cell repopulation and endothelialization }\end{array}$ & $\begin{array}{l}2011 \\
{[83]}\end{array}$ \\
\hline \multicolumn{5}{|l|}{ In-situ cell-free TEHV } \\
\hline $\begin{array}{l}\text { Decellularized ovine } \\
\text { aortic valve }\end{array}$ & - & $\begin{array}{l}\text { surgical replacement of the aortic valve } \\
\text { of adult sheep }\end{array}$ & $\begin{array}{l}9 \text { months follow-up } \\
\text { sufficient functionality } \\
\text { no degeneration } \\
\text { minor calcifications }\end{array}$ & $\begin{array}{l}2009 \\
{[84]}\end{array}$ \\
\hline $\mathrm{PGA}+\mathrm{P} 4 \mathrm{HB}$ & $\begin{array}{l}\text { MyoFBs, then } \\
\text { decellularized }\end{array}$ & $\begin{array}{l}\text { transcathether replacement of the } \\
\text { pulmonary valve of Chacma baboons }\end{array}$ & $\begin{array}{l}8 \text { weeks follow-up } \\
\text { mobile and thin leaflets } \\
\text { recellularization and } \\
\text { endothelialization }\end{array}$ & $\begin{array}{l}2013 \\
{[45]}\end{array}$ \\
\hline $\mathrm{PGA}+\mathrm{P} 4 \mathrm{HB}$ & $\begin{array}{l}\text { MyoFBs, then } \\
\text { decellularized }\end{array}$ & $\begin{array}{l}\text { transcathether replacement of the } \\
\text { pulmonary valve of adult sheep }\end{array}$ & $\begin{array}{l}24 \text { weeks follow-up } \\
\text { ECM remodeling and host cell repopulation } \\
\text { compromised coaptation at late time points }\end{array}$ & $\begin{array}{l}2014 \\
{[44]}\end{array}$ \\
\hline $\begin{array}{l}\text { Decellularized } \\
\text { porcine aortic } \\
\text { valve }\end{array}$ & - & $\begin{array}{l}\text { surgical replacement of the aortic valve } \\
\text { of adult pigs }\end{array}$ & $\begin{array}{l}15 \text { months follow-up } \\
\text { adequate functionality } \\
\text { cell repopulation and remodeling } \\
\text { vasa vasorum }\end{array}$ & $\begin{array}{l}2014 \\
{[85]}\end{array}$ \\
\hline Fibrin & $\begin{array}{l}\text { dermal FBs, then } \\
\text { decellularized }\end{array}$ & $\begin{array}{l}\text { surgical replacement of the aortic valve } \\
\text { of adult sheep }\end{array}$ & $\begin{array}{l}24 \text { weeks follow-up } \\
\text { ECM remodeling and host cell repopulation; } \\
\text { no calcification } \\
\text { good functionality }\end{array}$ & $\begin{array}{l}2015 \\
{[36]}\end{array}$ \\
\hline
\end{tabular}

cellularized xenografts cultured in vitro with myofibroblast and endothelial cells showed enhanced in vivo functionality and endothelialization in a sheep model [24]. Compared to xenogeneic tissues, allogeneic valves favor proliferation, differentiation, and survival of the seeded cells [25], but the availability of valve allografts is limited by donor shortage. Therefore, easily available bio- degradable synthetic and natural polymers have been extensively applied and proved to be suitable for the fabrication of in vitro TEHVs based on autologous cells and bioreactor systems to enhance cell proliferation and tissue formation. Promising results were reported by several groups for both in vitro [19, 26-28] and in vivo models [22, 29-36] (table 1). In 1995, Shinoka and colleagues 
[37] were the first to successfully implant in lamb a tissue-engineered leaflet based on the biodegradable polymer PGA and on autologous vascular-derived cells. In a similar approach, Hoerstrup et al. [29] showed physiological-like mechanical behavior and signs of remodeling and endothelialization of a TEHV implanted in the pulmonary position in lambs. More recently, the possibility to merge the TEHVs with the innovative, minimally invasive transcathether technique was proven feasible in sheep [33].

Despite encouraging early results, thickening of the leaflets has been observed in several studies in which in vitro cultured autologous cells were used $[31,33]$. The thickening, due to excessive ECM formation [38], is most likely an effect of the immune response towards the in vitro expanded cells present in the valves [39] and results in leaflet retraction and consequent valve insufficiency [33].

\section{In situ TEHVs}

The in situ tissue engineering approach relies on the regenerative capacity of the body to remodel and form new tissue by recruiting endogenous (circulating) cells while the scaffold degrades over time after providing the initial mechanical functionality [15, 16]. When compared to the classical in vitro method, this technique represents a straightforward alternative to produce off-theshelf available implants that are designed to guide and control cell recruitment and remodeling towards a native-like functional living tissue [16]. The cell-free scaffold is particularly important for this approach, as it should possess sufficient mechanical properties immediately upon implantation and favor endogenous cell adhesion and growth. Being allogeneic tissues hardly available, decellularized xenogeneic materials have gained large interest for this application [13], showing promising functionality and re-cellularization upon implantation in sheep [40], pigs [41], and dogs [42] (table 1). Nevertheless, the risk for disease transmission and immune reaction to the use of xenogeneic materials have motivated researchers to develop new strategies to achieve engineered off-the-shelf available allogeneic valve replacements.

By decellularization of TEHVs obtained via the classic in vitro approach, we have obtained non-immunogenic valve substitutes with intact mechanical and biological properties [43]. This approach solved the thickening and retraction of the leaflets that was previously reported for living TEHVs [33], by introducing also the off-the-shelf availability of the product. In addition, it can be efficiently combined with the transcathether approach, without limiting valve functionality and remodeling potential, as demonstrated in sheep [44] and baboons [45]. With a similar approach, others investigated the use of fibrin-based decellularized TEHVs, showing good in vitro [46] and in vivo functionality, with almost complete cell repopulation in the systemic circulation of sheep [36]. Despite the promising pre-clinical results of these decellularized valves, the time and cost associated with scaffold production pushed the researchers to develop new alternatives. Cell-free, readily available valves can be produced by using biodegradable and biocompatible polymeric materials; upon implantation, the polymer will provide a suitable environment for endogenous cell adhesion, and support ECM formation and remodeling towards a completely autologous tissue replacement when the starting material is fully degraded [47].

\section{Other Tissue Engineering Approaches}

Another method to reduce the time and costs associated with the in vitro production of TEHVs is the pre-seeding of the scaffold with autologous cells. Although the most appropriate cell type for in vitro pre-seeding is not established yet, bone marrow-derived mesenchymal stem cells (MSCs) proved to be an attractive cell source. In fact, they were successfully used to re-seed decellularized matrices [25] and synthetic scaffolds [19, 35], showing differentiation into a phenotype similar to valvular interstitial cells [48]. These cells also demonstrated anti-thrombogenic potential [49] and immunosuppressive properties [50], the ability to stimulate in vivo endothelialization [51], and differentiation potential into endothelial cells, (myo)fibroblasts, and smooth muscle cells [25]. Importantly, MSCs are easy to access, facilitating their translation into clinical practice [52]. Importantly, they may induce the homing and differentiation of autologous host cells through a paracrine secretion of growth and chemotactic factors [53].

Another line of research, defined as in vivo tissue engineering, focus on exploiting the foreign body reaction upon subcutaneous implantation (e.g., in the peritoneal cavity) of a non-degradable mold. The formed fibrotic collagen-rich matrix encapsulating the foreign material [54] follows the shape of the mold, creating a TEHV [55]. The construct can be harvested and transplanted as a non-immunogenic, non-toxic, autologous replacement that may possess growth and regenerative capacity. A similar prototype has been tested under pulmonary conditions in vitro [55] and implanted using minimally invasive transcathether techniques as aortic replacements in a recent study in goats [56]. Despite the early positive results, the remodeling of the collagenous matrix is questionable in humans: the thickness of the fibrotic capsule formed around the mold is uncontrollable, and the method is highly invasive, requiring long in vivo pre-transplantation time to obtain mechanically robust grafts [57], making it an unsuitable techniques for emergency cases.

\section{Clinical Translation of Tissue-Engineered Valve Replacements}

Novel engineered valves with repair and growth capacity have the potential to provide a permanent solution for pediatric and young adult patients. However, the clinical adaptation of regenerative valve replacements depends on their superiority compared to today's bioprostheses in terms of functionality and durability. Clinical trials have already been performed to investigate the functionality and remodeling potential of in vitro TEHVs based on decel- 
Table 2. Overview of clinical studies investigating the potentiality of in vitro TEHVs using decellularized pulmonary allografts and xenografts as starting scaffold material

\begin{tabular}{|c|c|c|c|c|}
\hline Cells & Culture & Patient cohort & Main results & Year \\
\hline \multicolumn{5}{|l|}{ Allografts } \\
\hline Autologous vascular ECs & 4 weeks in bioreactor & 1 adult patient & $\begin{array}{l}1 \text { year follow-up } \\
\text { excellent functionality }\end{array}$ & $\begin{array}{l}2002 \\
{[58]}\end{array}$ \\
\hline $\begin{array}{l}\text { Autologous blood progenitor } \\
\text { cells }\end{array}$ & 3 weeks in bioreactor & 2 pediatric patients & $\begin{array}{l}3 \text { years follow-up } \\
\text { safe and feasible procedure } \\
\text { good functionality, even if mild to moderate regurgitation }\end{array}$ & $\begin{array}{l}2006 \\
{[60]}\end{array}$ \\
\hline Autologous vascular ECs & 4 weeks in bioreactor & 11 patients & $\begin{array}{l}10 \text { year follow-up } \\
\text { excellent hemodynamics } \\
\text { no signs of degeneration or calcification }\end{array}$ & $\begin{array}{l}2011 \\
{[59]}\end{array}$ \\
\hline \multicolumn{5}{|l|}{ Xenografts } \\
\hline Autologous vascular ECs & 4 weeks in bioreactor & 12 patients & $\begin{array}{l}5 \text { years follow-up } \\
\text { good functionality } \\
\text { no signs of degeneration }\end{array}$ & $\begin{array}{l}2007 \\
{[18]}\end{array}$ \\
\hline
\end{tabular}

lularized allografts [58-60] and xenografts [18], seeded and cultured with endothelial cells prior to implantation (table 2). By targeting the capability of the body to self-regenerate, cell-free decellularized matrixes have also been tested in clinics as scaffold materials for the in situ approach (table 3).

Despite the enormous progress in the development of TEHVs that show regenerative potential in the pre-clinical studies (table 1) and the clinical trials exploring the potentiality of the tissue engineering approaches (tables 2,3 ), a clinically relevant product is not yet realized, and many technical, regulatory, and clinical challenges still need to be solved.

\section{Technical Challenges: Cell and Scaffold Optimization}

To prevent in vivo deterioration, TEHVs should be able to regenerate similarly to the native valve, where valvular interstitial cells synthesize and remodel the ECM ensuring growth and repair [61].

Seeding and culturing endothelial and endothelial progenitor cells proved to be a valuable method to reduce scaffold thrombogenicity and inflammatory response (table 2). In vitro cultured TEHVs based on decellularized human pulmonary valves seeded with endothelial cells have demonstrated excellent hemodynamic performance and good functionality in clinical trials up to 10 years [59]. Thanks to the good functionality and the lack of degeneration, calcification and immunoreactivity, the use of decellularized allografts for both pulmonary and aortic valves is promising, with minimal occurrence of re-operations and possibility for adaptive growth $[62,63]$. Unfortunately, the availability of allografts is limited by donor shortage, leaving unmet the need for off-the-shelf available regenerative heart valve replacements. Clinical translation of the easily accessible xenogeneic valves, based on decellularized porcine tissues, has contradictory results, with reported sudden structural failure, severe stenosis, and need for re-operation in above $50 \%$ of the patients [64-66]. The causes of these failures reside in the residual immunogenicity of the decellularized xenoge- neic tissue that determines a severe inflammatory response [64, 67]. These dramatic results underline the preference for allogeneic material for clinical application and exemplify the need for novel alternative valves.

As the applicability of autologous in vitro cultured TEHVs is limited by the donor-to-donor variability and logistical hurdles, the use of an off-the-shelf available decellularized engineered valve may provide a solution. The less mature, in vitro grown ECM of the decellularized tissue-engineered matrices is hypothesized to allow for enhanced cell infiltration, leading to better repopulation capacity upon in vivo implantation [44]. However, the complete decellularization of the tissue is crucial as residual cells and cell remnants might lead to a strong inflammatory response and valve calcification [68].

Scaffold geometry and material porosity determine the level of cell infiltration and can be controlled using different methods of scaffold fabrication (e.g., electrospinning, mold casting, particulate leaching, and 3D-printing) [69]. Additionally, by immobilizing specific biomolecules (e.g., proteins, peptides, and antibodies), improved biocompatibility as well as cell recruitment and differentiation can be obtained [15]. As an example, the controlled release of inflammatory cytokines and chemokines (e.g., IL-8 and monocyte chemotactic protein-1), which are potent cell attractants and activators, was hypothesized to determine the fate of the implanted scaffold towards either a successful integration or a pathological chronic outcome [53].

In order to profit from the full potential of scaffold materials for in situ tissue engineering, multidisciplinary in-depth knowledge on the material properties, scaffold design, and scaffold functionalization is required.

\section{Clinical Challenges: Beating the Gold Standard Valve Replacements}

To encourage the adaptation of the TEHVs in routine clinical practice the off-the-shelf availability and the sterility of the product 
Table 3. Overview of clinical studies investigating the potentiality of in-situ TEHVs based on decellularized allografts and xenografts as scaffold material

\begin{tabular}{|c|c|c|c|c|}
\hline Type of valve & Surgical procedure & Patient cohort & Main results & Year \\
\hline \multicolumn{5}{|l|}{ Allografts } \\
\hline $\begin{array}{l}\text { Decellularized pulmonary } \\
\text { valve }\end{array}$ & Ross procedure & 15 patients & $\begin{array}{l}6 \text { months follow-up } \\
\text { promising hemodynamics and functionality } \\
\text { good morphology }\end{array}$ & $\begin{array}{l}2003 \\
{[86]}\end{array}$ \\
\hline $\begin{array}{l}\text { Decellularized pulmonary } \\
\text { valve }\end{array}$ & Ross procedure & 11 patients & $\begin{array}{l}18 \text { months follow-up } \\
\text { reduction of the immunogenic response } \\
\text { promising functionality }\end{array}$ & $\begin{array}{l}2005 \\
{[87]}\end{array}$ \\
\hline Decellularized aortic valve & aortic root replacement & 22 patients & $\begin{array}{l}1 \text { year follow-up } \\
\text { good functionality } \\
\text { low to none immunoreactivity }\end{array}$ & $\begin{array}{l}2005 \\
{[88]}\end{array}$ \\
\hline Decellularized aortic valve & aortic root replacement & 41 patients & $\begin{array}{l}4 \text { years follow-up } \\
\text { adequate hemodynamics } \\
\text { structural integrity over time } \\
\text { no calcification }\end{array}$ & $\begin{array}{l}2010 \\
{[89]}\end{array}$ \\
\hline $\begin{array}{l}\text { Decellularized pulmonary } \\
\text { valve }\end{array}$ & Ross procedure & 29 patients & $\begin{array}{l}5 \text { years follow-up } \\
\text { promising functionality and hemodynamic profile }\end{array}$ & $\begin{array}{l}2011 \\
{[90]}\end{array}$ \\
\hline $\begin{array}{l}\text { Decellularized pulmonary } \\
\text { valve }\end{array}$ & $\begin{array}{l}\text { pulmonary valve } \\
\text { replacement }\end{array}$ & 38 patients & $\begin{array}{l}5 \text { years follow-up } \\
100 \% \text { freedom from re-operation } \\
\text { adaptive growth in pediatric patients }\end{array}$ & $\begin{array}{l}2011 \\
{[62]}\end{array}$ \\
\hline $\begin{array}{l}\text { Decellularized pulmonary } \\
\text { valve }\end{array}$ & $\begin{array}{l}\text { pulmonary valve } \\
\text { replacement }\end{array}$ & 93 patients & $\begin{array}{l}10 \text { years follow-up } \\
100 \% \text { freedom from re-operation } \\
\text { good functionality and hemodynamic profile }\end{array}$ & $\begin{array}{l}2016 \\
{[63]}\end{array}$ \\
\hline \multicolumn{5}{|l|}{ Xenografts } \\
\hline $\begin{array}{l}\text { Decellularized porcine } \\
\text { valve }\end{array}$ & Ross procedure & 50 patients & $\begin{array}{l}2 \text { years follow-up } \\
\text { physiological-like behavior } \\
36 \% \text { needed a re-operation }\end{array}$ & $\begin{array}{l}2005 \\
{[91]}\end{array}$ \\
\hline $\begin{array}{l}\text { Decellularized porcine } \\
\text { valve }\end{array}$ & $\begin{array}{l}\text { pulmonary valve } \\
\text { replacement }\end{array}$ & 16 young patients & $\begin{array}{l}\text { stenosis } \\
\text { severe thickening of the intima }\end{array}$ & $\begin{array}{l}2010 \\
{[66]}\end{array}$ \\
\hline $\begin{array}{l}\text { Decellularized porcine } \\
\text { valve }\end{array}$ & $\begin{array}{l}\text { right ventricle outflow } \\
\text { tract }\end{array}$ & $\begin{array}{l}61 \text { patients } \\
\text { (18 in infancy) }\end{array}$ & $\begin{array}{l}3 \text { years follow-up } \\
100 \% \text { freedom of re-operation for pediatric patients } \\
\text { favorable performance and functionality }\end{array}$ & $\begin{array}{l}2011 \\
{[92]}\end{array}$ \\
\hline $\begin{array}{l}\text { Decellularized porcine } \\
\text { valve }\end{array}$ & $\begin{array}{l}\text { pulmonary valve } \\
\text { replacement }\end{array}$ & 26 young patients & $\begin{array}{l}\text { average life span of } 19 \text { months } \\
14 \text { failures that required re-operation } \\
\text { stenosis and insufficiency of the valve } \\
\text { foreign body response and inflammation } \\
\text { no endothelial cell coverage }\end{array}$ & $\begin{array}{l}2013 \\
{[65]}\end{array}$ \\
\hline
\end{tabular}

as well as the ease of handling of the device and suitability for the different implantation techniques are highly relevant. Minimally invasive transcathether implantation techniques have had a rapid evolution in the past 10 years, reducing the risks and costs associated with the intervention. Being limited only to the use of bioprostheses, the transcathether techniques can be potentially combined with the different types of TEHVs, as demonstrated in sheep $[33,44,70]$, goats [56], and baboons [45]. In addition, the feasibility of combining TEHVs with a clinically used stent and delivery device was also recently shown [71]. Still, to enable the full regenerative potential of transcathether valves, this approach should be complemented by innovative stent designs that allow for controlled dilatation or reabsorption upon implantation [72].

In addition, the different regenerative potential among patients is of great concern, because cell infiltration, adhesion, and ECM production may be age-dependent and influenced by comorbidities. To predict the clinical outcome from the results of pre-clinical experiments, a clear correlation between animal and human data has to be identified. The development of specific in vitro model systems would be beneficial to study the inter-patient and interspecies variability in the response to the implanted materials. Further, the phenotype of the macrophages recruited into the implanted scaffold can potentially forecast the direction of the in vivo remodeling response to either chronic inflammation or healing [73].

Clinical success of the TEHV replacements depends on logistics considerations: off-the-shelf availability, ease of storage, and transportation. For replacements based on living cells, the only method to increase the product lifetime is by cryopreservation. To limit damage to the tissue caused by the freezing process [74], researchers have introduced the use of different methods (e.g., cryoprotective media [75] and vitrification [76]) to control the ice crystal formation. Similarly, lyophilization can improve the shelf life of decellularized tissues or engineered matrix. To retain the structural in- 
tegrity and the final geometry of the product, the use of sucrose solution and/or the optimization of the freezing cycle temperatures may be necessary [77]. Finally, biodegradable polymer-based TEHVs for in situ applications do not require special processing, gaining further interest in the community.

Optimization of the processes required to ensure product sterility, availability, ease of handling, storage, and transportation will lead to the clinical success of the TEHV replacements.

\section{Regulatory Challenges: Towards Commercialization}

The growing market for heart valve prostheses, valued at USD 2.87 billion in 2014 and estimated to grow to USD 4.80 billion by 2020 [2], attracts the attention of many biomedical companies. However, the novel TEHVs are difficult to assign in the classical Food and Drug Administration (FDA) classification. In fact, devices containing living cells that have a clear pharmacological, immunological, or metabolic effect on the human body are usually classified as biological or pharmaceutical products. At the same time, decellularized materials or tissue-engineered constructs, where the matrix is the major mechanism of action and the function occurs by physical means (e.g., heart valves, blood vessels), can be either classified as medical or biological devices. Therefore, there is still the need for the FDA and other regulatory agencies worldwide to formulate regulations and documents to clarify these issues [78].

Before moving from bench to bedside, the production and testing of the TEHVs should be performed in accordance to technical norms (e.g., ISO 13485 Medical Devices - Quality Management System - Requirements for Regulatory Purposes [79]; ISO 10993 Biological Evaluation of Medical Devices [80]; ISO 5840 Cardiovascular Implants - Cardiac Valve Prosthesis [81]) and the product should be evaluated by an accredited notified body. To be able to accommodate for the different technical guidelines and requirements of Europe, Japan and the USA, the production, pre-clinical and clinical evaluation of the product should be performed in accordance to the International Council on Harmonisation of Technical Requirements for Registration of Pharmaceuticals for Human Use (ICH). The ICH guidelines aim at ensuring safety (e.g., to uncover potential risks like carcinogenicity or genotoxicity), quality (e.g., stability studies, definition of thresholds for impurities, and good manufacturing practice compliance), and efficacy (e.g., related to the design, conduct, safet,y and reporting of clinical trials) of the product.

The process of harmonization would lead to the production of a product ready for commercialization in the different areas, while ensuring quality, safety, efficacy, and regulatory obligations to protect public health.

\section{Conclusions}

Lifetime expectancy is constantly increasing, leading to more and more patients in need of a valve replacement with prolonged durability. In order to solve this problem, several tissue engineering approaches have been developed over the last years, showing promising in vitro, pre-clinical, and even clinical results. Engineered valve replacements with regenerative capacity have the potential to offer a lifelong solution for the increasing numbers of cardiovascular patients worldwide. However, their translation into clinics depends on their superiority compared to today's bioprosthetic valves. Despite the enormous progress in the development of TEHVs that have showed regenerative potential in pre-clinical studies, a clinically relevant product is not yet realized. Therefore, research in the field of cardiovascular tissue engineering should focus on the understanding of the structural and biological properties of the native valves that ensure its efficiency and functionality. The most recently introduced in situ approaches that enable offthe-shelf availability and exploit the regenerative capacity of the body to remodel and form new tissue upon orthotopic implantation were reviewed here. These prostheses hold large promises for clinical translation, as they represent a less complex and substantially less costly alternative to replacements obtained via the classic in vitro tissue engineering paradigm. By improving scaffold fabrication strategies, it will become possible to replicate the physiological complexity and instruct cell differentiation and remodeling of seeded or endogenously recruited cells. Despite the necessary future developments, preclinical results demonstrated that engineered artificial valves do bare regenerative capacity and promise to improve the quality of life of younger and older patients alike.

\section{Acknowledgements}

The authors have received funding from the European Union's Seventh Framework Programme (FP7/2007-2013) under grant agreement no. 626976 (LivaGraft) and acknowledge the support from the Netherlands Cardio Vascular Research Initiative: The Dutch Heart Foundation, the Dutch Federation of University Medical Centres, the Netherlands Organisation for Health Research and Development, and the Royal Netherlands Academy of Sciences (1-Valve).

\section{Disclosure Statement}

The authors declare no competing interests. 


\section{References}

1 Manji RA, Ekser B, Menkis AH, Cooper DK: Bioprosthetic heart valves of the future. Xenotransplantation 2014;21:1-10.

2 Prosthetic heart valve market by type (mechanical, transcatheter, tissue), and geography (Americas, Europe, Asia-Pacific, Middle East \& Africa) - global forecast to 2020. www.marketsandmarkets.com/MarketReports/prosthetic-heart-valve-market-245407958.html (last accessed July 6, 2016).

3 Soliman Hamad MA, van Eekelen E, van Agt T, van Straten AH: Self-management program improves anticoagulation control and quality of life: a prospective randomized study. Eur J Cardiothorac Surg 2009;35: 265-269.

4 Alsoufi B: Aortic valve replacement in children: options and outcomes. J Saudi Heart Assoc 2014;26:3341.

5 Brown ML, McKellar SH, Sundt TM, Schaff HV: Ministernotomy versus conventional sternotomy for aortic valve replacement: a systematic review and meta-analysis. J Thorac Cardiovasc Surg 2009;137:670-679.e5.

6 Schoen FJ, Gotlieb AI: Heart valve health, disease, replacement, and repair: a 25-year cardiovascular pathology perspective. Cardiovasc Pathol 2016;25:341-352.

7 Luk A, Rao V, Cusimano RJ, David TE, Butany J: Cormatrix extracellular matrix used for valve repair in the adult: is there de novo valvular tissue seen? Ann Thorac Surg 2015;99:2205-2207.

8 Cribier A, Eltchaninoff H, Bash A, Borenstein N, Tron C, Bauer F, Derumeaux G, Anselme F, Laborde F, Leon MB: Percutaneous transcatheter implantation of an aortic valve prosthesis for calcific aortic stenosis: First human case description. Circulation 2002;106:3006-3008

9 Rabkin-Aikawa E, Mayer JE, Schoen FJ: Heart valve regeneration. Adv Biochem Eng Biotechnol 2005;94: 141-179.

10 Mendelson K, Schoen FJ: Heart valve tissue engineering: concepts, approaches, progress, and challenges. Ann Biomed Eng 2006;34:1799-1819.

11 Langer R, Vacanti JP: Tissue engineering. Science 1993;260:920-926.

12 Tedder ME, Simionescu A, Chen J, Liao J, Simionescu DT: Assembly and testing of stem cell-seeded layered collagen constructs for heart valve tissue engineering. Tissue Eng Part A 2011;17:25-36.

13 Kasimir MT, Rieder E, Seebacher G, Silberhumer G, Wolner E, Weigel G, Simon P: Comparison of different decellularization procedures of porcine heart valves. Int J Artif Organs 2003;26:421-427.

14 Cheung DY, Duan B, Butcher JT: Current progress in tissue engineering of heart valves: multiscale problems, multiscale solutions. Expert Opin Biol Ther 2015;15: $1155-1172$.

15 van Loon SLM, Smits AIPM, Driessen-Mol A, Baaijens FPT, Bouten CVC: The immune response in in situ tissue engineering of aortic heart valves; in Aikawa $\mathrm{E}$ (ed): Calcific Aortic Valve Disease. Rijeka, InTech, 2013, pp 207-245.

16 Bouten CV, Dankers PY, Driessen-Mol A, Pedron S, Brizard AM, Baaijens FP: Substrates for cardiovascular tissue engineering. Adv Drug Deliv Rev 2011;63:221241.

17 Rieder E, Kasimir MT, Silberhumer G, Seebacher G, Wolner E, Simon P, Weigel G: Decellularization protocols of porcine heart valves differ importantly in efficiency of cell removal and susceptibility of the matrix to recellularization with human vascular cells. J Thorac Cardiovasc Surg 2004;127:399-405.

18 Dohmen PM, Lembcke A, Holinski S, Kivelitz D, Braun JP, Pruss A, Konertz W: Mid-term clinical results using a tissue-engineered pulmonary valve to reconstruct the right ventricular outflow tract during the ross procedure. Ann Thorac Surg 2007;84:729-736.
Hoerstrup SP, Kadner A, Melnitchouk S, Trojan A, Eid K, Tracy J, Sodian R, Visjager JF, Kolb SA, Grunenfelder J, Zund G, Turina MI: Tissue engineering of functional trileaflet heart valves from human marrow stromal cells. Circulation 2002;106(12 suppl 1):I143-I150.

20 Schmidt D, Achermann J, Odermatt B, Breymann C, Mol A, Genoni M, Zund G, Hoerstrup SP: Prenatally fabricated autologous human living heart valves based on amniotic fluid derived progenitor cells as single cell source. Circulation 2007;116(11 suppl):I64-I70.

21 Sales VL, Mettler BA, Engelmayr GC, Aikawa E, Bischoff J, Martin DP, Exarhopoulos A, Moses M, Schoen FJ, Sacks M, Mayer J: Endothelial progenitor cells as a sole source for ex vivo seeding of tissue-engineered heart valves. Tissue Eng Part A. 2010;16:257-267.

22 Sodian R, Schaefermeier P, Begg-Zips S, Kuebler WM, Shakibaei M, Daebritz S, Ziegelmueller J, Schmitz C, Reichart B: Use of human umbilical cord bloodderived progenitor cells for tissue-engineered heart valves. Ann Thorac Surg 2010;89:819-828.

23 Frese L, Sanders B, Beer GM, Weber B, Driessen-Mol A, Baaijens FPT, Hoerstrup SP: Adipose derived tissue engineered heart valve. J Tissue Sci Eng 2015;6:156.

24 Lichtenberg A, Tudorache I, Cebotari S, Suprunov M, Tudorache G, Goerler H, Park JK, Hilfiker-Kleiner D, Ringes-Lichtenberg S, Karck M, Brandes G, Hilfiker A, Haverich A: Preclinical testing of tissue-engineered heart valves re-endothelialized under simulated physiological conditions. Circulation 2006;114(1 suppl): I559-I565.

25 Iop L, Renier V, Naso F, Piccoli M, Bonetti A, Gandaglia A, Pozzobon M, Paolin A, Ortolani F, Marchini M, Spina M, De Coppi P, Sartore S, Gerosa G: The influence of heart valve leaflet matrix characteristics on the interaction between human mesenchymal stem cells and decellularized scaffolds. Biomaterials 2009;30: 4104-4116.

$26 \mathrm{Mol}$ A, Driessen NJ, Rutten MC, Hoerstrup SP, Bouten $\mathrm{CV}$, Baaijens FP: Tissue engineering of human heart valve leaflets: a novel bioreactor for a strain-based conditioning approach. Ann Biomed Eng 2005;33:17781788.

27 Del Gaudio C, Bianco A, Grigioni M: Electrospun bioresorbable trileaflet heart valve prosthesis for tissue engineering: in vitro functional assessment of a pulmonary cardiac valve design. Ann Ist Super Sanita 2008; 44:178-186.

28 Sodian R, Hoerstrup SP, Sperling JS, Daebritz SH, Martin DP, Schoen FJ, Vacanti JP, Mayer JEJ: Tissue engineering of heart valves: in vitro experiences. Ann Thorac Surg 2000;70:140-144.

29 Hoerstrup SP, Sodian R, Daebritz S, Wang J, Bacha EA, Martin DP, Moran AM, Guleserian KJ, Sperling JS, Kaushal S, Vacanti JP, Schoen FJ, Mayer JE Jr: Functional living trileaflet heart valves grown in vitro. Circulation 2000;102(19 suppl 3):III44-49.

30 Robinson PS, Johnson SL, Evans MC, Barocas VH, Tranquillo RT: Functional tissue-engineered valves from cell-remodeled fibrin with commissural alignment of cell-produced collagen. Tissue Eng Part A 2008;14:83-95.

31 Gottlieb D, Kunal T, Emani S, Aikawa E, Brown DW, Powell AJ, Nedder A, Engelmayr GC, Jr., Melero-Martin JM, Sacks MS, Mayer JE Jr: In vivo monitoring of function of autologous engineered pulmonary valve. J Thorac Cardiovasc Surg 2010;139:723-731.

32 Flanagan TC, Sachweh JS, Frese J, Schnöring H, Gronloh N, Koch S, Tolba RH, Schmitz-Rode T, Jockenhoevel S: In vivo remodeling and structural characterization of fibrin-based tissue-engineered heart valves in the adult sheep model. Tissue Eng Part A 2009;15: 2965-2976.
3 Schmidt D, Dijkman PE, Driessen-Mol A, Stenger R, Mariani C, Puolakka A, Rissanen M, Deichmann T, Odermatt B, Weber B, Emmert MY, Zund G, Baaijens FP, Hoerstrup SP: Minimally-invasive implantation of living tissue engineered heart valves: a comprehensive approach from autologous vascular cells to stem cells. J Am Coll Cardiol 2010;56:510-520.

34 Stock UA, Nagashima M, Khalil PN, Nollert GD, Herden T, Sperling JS, Moran A, Lien J, Martin DP, Schoen FJ, Vacanti JP, Mayer JEJ: Tissue-engineered valved conduits in the pulmonary circulation. J Thorac Cardiovasc Surg 2000;119:732-740.

35 Sutherland FWH, Perry TE, Yu Y, Sherwood MC, Rabkin E, Masuda Y, Garcia GA, McLellan DL, Engelmayr GCJ, Sacks MS, Schoen FJ, Mayer JEJ: From stem cells to viable autologous semilunar heart valve. Circulation 2005;111:2783-2791.

36 Syedain Z, Reimer J, Schmidt J, Lahti M, Berry J, Bianco R, Tranquillo RT: 6-month aortic valve implantation of an off-the-shelf tissue-engineered valve in sheep. Biomaterials 2015;73:175-184.

37 Shinoka T, Breuer CK, Tanel RE, Zund G, Miura T, Ma PX, Langer R, Vacanti JP, Mayer JE Jr: Tissue engineering heart valves: valve leaflet replacement study in a lamb model. Ann Thorac Surg 1995;60(6 suppl): S513-516.

38 Steinhoff G, Stock U, Karim N, Mertsching H, Timke A, Meliss RR, Pethig K, Haverich A, Bader A: Tissue engineering of pulmonary heart valves on allogenic acellular matrix conduits: in vivo restoration of valve tissue. Circulation 2000;102(19 suppl 3):III50-III55.

39 Dijkman PE, Driessen-Mol A, de Heer LM, Kluin J, van Herwerden LA, Odermatt B, Baaijens FP, Hoerstrup SP: Trans-apical versus surgical implantation of autologous ovine tissue-engineered heart valves. J Heart Valve Dis 2012;21:670-678.

40 Jordan JE, Williams JK, Lee SJ, Raghavan D, Atala A, Yoo JJ: Bioengineered self-seeding heart valves. J Thorac Cardiovasc Surg 2012;143:201-208.

41 Honge JL, Funder J, Hansen E, Dohmen PM, Konertz W, Hasenkam JM: Recellularization of aortic valves in pigs. Eur J Cardiothorac Surg 2011;39:829-834.

42 Ota T, Taketani S, Iwai S, Miyagawa S, Furuta M, Hara M, Uchimura E, Okita Y, Sawa Y: Novel method of decellularization of porcine valves using polyethylene glycol and gamma irradiation. Ann Thorac Surg 2007; 83:1501-1507.

43 Dijkman PE, Driessen-Mol A, Frese L, Hoerstrup SP, Baaijens FP: Decellularized homologous tissue-engineered heart valves as off-the-shelf alternatives to xeno- and homografts. Biomaterials 2012;33:45454554.

44 Driessen-Mol A, Emmert MY, Dijkman PE, Frese L, Sanders B, Weber B, Cesarovic N, Sidler M, Leenders J, Jenni R, Grunenfelder J, Falk V, Baaijens FP, Hoerstrup SP: Transcatheter implantation of homologous 'off-the-shelf' tissue-engineered heart valves with selfrepair capacity: long-term functionality and rapid in vivo remodeling in sheep. J Am Coll Cardiol 2014;63: 1320-1329.

45 Weber B, Dijkman PE, Scherman J, Sanders B, Emmert MY, Grunenfelder J, Verbeek R, Bracher M, Black M, Franz T, Kortsmit J, Modregger P, Peter S, Stampanoni M, Robert J, Kehl D, van Doeselaar M, Schweiger M, Brokopp CE, Walchli T, Falk V, Zilla P, Driessen-Mol A, Baaijens FP, Hoerstrup SP: Off-the-shelf human decellularized tissue-engineered heart valves in a nonhuman primate model. Biomaterials 2013;34:7269-7280.

46 Reimer JM, Syedain ZH, Haynie BH, Tranquillo RT: Pediatric tubular pulmonary heart valve from decellularized engineered tissue tubes. Biomaterials 2015;62: $88-94$. 
$47 \mathrm{Mol} \mathrm{A}$, Smits A, Bouten C, Baaijens F: Tissue engineering of heart valves: advances and current challanges. Expert Rev Med Devices 2009;6:259-275.

48 Latif N, Sarathchandra P, Thomas PS, Antoniw J, Batten P, Chester AH, Taylor PM, Yacoub MH: Characterization of structural and signaling molecules by human valve interstitial cells and comparison to human mesenchymal stem cells. J Heart Valve Dis 2007; 16:56-66.

49 Hashi CK, Zhu Y, Yang GY, Young WL, Hsiao BS, Wang K, Chu B, Li S: Antithrombogenic property of bone marrow mesenchymal stem cells in nanofibrous vascular grafts. Proc Natl Acad Sci U S A 2007;104: 11915-11920.

50 Uccelli A, Moretta L, Pistoia V: Immunoregulatory function of mesenchymal stem cells. Eur J Immunol 2006;36:2566-2573.

51 Mirza A, Hyvelin JM, Rochefort GY, Lermusiaux P, Antier D, Awede B, Bonnet P, Domenech J, Eder V: Undifferentiated mesenchymal stem cells seeded on a vascular prosthesis contribute to the restoration of a physiologic vascular wall. J Vasc Surg 2008;47:1313-1321.

52 Pittenger MF, Martin BJ: Mesenchymal stem cells and their potential as cardiac therapeutics. Circ Res 2004; 95:9-20.

53 Roh JD, Sawh-Martinez R, Brennan MP, Jay SM, Devine L, Rao DA, Yi T, Mirensky TL, Nalbandian A, Udelsman B, Hibino N, Shinoka T, Saltzman WM, Snyder E, Kyriakides TR, Pober JS, Breuer CK: Tissueengineered vascular grafts transform into mature blood vessels via an inflammation-mediated process of vascular remodeling. Proc Natl Acad Sci U S A 2010; 107:4669-4674.

54 Hayashida K, Kanda K, Oie T, Okamoto Y, IshibashiUeda H, Onoyama M, Tajikawa T, Ohba K, Yaku H, Nakayama Y: Architecture of an in vivo-tissue engineered autologous conduit 'biovalve'. J Biomed Mater Res B Appl Biomater 2008;86:1-8.

55 Sumikura H, Nakayama Y, Ohnuma K, Kishimoto S, Takewa Y, Tatsumi E: In vitro hydrodynamic evaluation of a biovalve with stent (tubular leaflet type) for transcatheter pulmonary valve implantation. J Artif Organs 2015;18:307-314.

56 Kishimoto S, Takewa Y, Nakayama Y, Date K, Sumikura H, Moriwaki T, Nishimura M, Tatsumi E: Sutureless aortic valve replacement using a novel autologous tissue heart valve with stent (stent biovalve): proof of concept. J Artif Organs 2015;18:185-190.

57 Nakayama Y, Kaneko Y, Takewa Y, Okumura N: Mechanical properties of human autologous tubular connective tissues (human biotubes) obtained from patients undergoing peritoneal dialysis. J Biomed Mater Res B Appl Biomater 2015; doi: 10.1002/jbm.b.33495.

58 Dohmen PM, Lembcke AH, Hotz H, Kivelitz D, Konertz WF: Ross operation with a tissue-engineered heart valve. Ann Thorac Surg 2002;74:1438-1442.

59 Dohmen PM, Lembcke A, Holinski S, Pruss A, Konertz $\mathrm{W}$ : Ten years of clinical results with a tissue-engineered pulmonary valve. Ann Thorac Surg 2011;92:1308-1314.

60 Cebotari S, Lichtenberg A, Tudorache I, Hilfiker A, Mertsching H, Leyh R, Breymann T, Kallenbach K, Maniuc L, Batrinac A, Repin O, Maliga O, Ciubotaru A, Haverich A: Clinical application of tissue engineered human heart valves using autologous progenitor cells. Circulation 2006;114(1 suppl):I132-137.

61 Gui L, Chan SA, Breuer CK, Niklason LE: Novel utilization of serum in tissue decellularization. Tissue Eng Part C Methods 2010;16:173-184.

62 Cebotari S, Tudorache I, Ciubotaru A, Boethig D, Sarikouch S, Goerler A, Lichtenberg A, Cheptanaru E, Barnaciuc S, Cazacu A, Maliga O, Repin O, Maniuc L, Breymann T, Haverich A: Use of fresh decellularized allografts for pulmonary valve replacement may reduce the reoperation rate in children and young adults: Early report. Circulation 2011;124(11 suppl):S115-123.
63 Sarikouch S, Horke A, Tudorache I, Beerbaum P, Westhoff-Bleck M, Boethig D, Repin O, Maniuc L, Ciubotaru A, Haverich A, Cebotari S: Decellularized fresh homografts for pulmonary valve replacement: A decade of clinical experience. Eur J Cardiothorac Surg 2016; doi: 10.1093/ejcts/ezw050.

64 Simon P, Kasimir MT, Seebacher G, Weigel G, Allrich R, Salzer-Muhar U, Rieder E, Wolner E: Early failure of the tissue engineered porcine heart valve synergraft in pediatric patients. Eur J Cardiothorac Surg 2003;23: 1002-1006.

65 Voges I, Brasen JH, Entenmann A, Scheid M, Scheewe J, Fischer G, Hart C, Andrade A, Pham HM, Kramer HH, Rickers C: Adverse results of a decellularized tissue-engineered pulmonary valve in humans assessed with magnetic resonance imaging. Eur J Cardiothorac Surg 2013;44:e272-279.

66 Ruffer A, Purbojo A, Cicha I, Glockler M, Potapov S, Dittrich S, Cesnjevar RA: Early failure of xenogenous de-cellularised pulmonary valve conduits-a word of caution! Eur J Cardiothorac Surg 2010;38:78-85.

67 Woo JS, Fishbein MC, Reemtsen B: Histologic examination of decellularized porcine intestinal submucosa extracellular matrix (cormatrix) in pediatric congenital heart surgery. Cardiovasc Pathol 2015;25:12-17.

68 Human P, Zilla P: Characterization of the immune response to valve bioprostheses and its role in primary tissue failure. Ann Thorac Surg 2001;71(5 suppl):S385S388.

69 Balguid A, Mol A, van Marion MH, Bank RA, Bouten CVC, Baaijens FPT: Tailoring fiber diameter in electrospun poly(epsilon-caprolactone) scaffolds for optimal cellular infiltration in cardiovascular tissue engineering. Tissue Eng Part A 2009;15:437-444.

70 Schmidt B, Spriestersbach H, O H-Ici D, Radtke T, Bartosch M, Peters H, Sigler M, Frese L, Dijkman P, Baaijens F, Hoerstrup SP, Berger F: Percutaneous pulmonary valve replacement using completely tissue-engineered off-the-shelf heart valves: six-month in vivo functionality and matrix remodelling in sheep. EuroIntervention 2016;12:62-70.

71 Emmert MY, Weber B, Behr L, Sammut S, Frauenfelder T, Wolint P, Scherman J, Bettex D, Grunenfelder J, Falk V, Hoerstrup SP: Transcatheter aortic valve implantation using anatomically oriented, marrow stromal cell-based, stented, tissue-engineered heart valves: technical considerations and implications for translational cell-based heart valve concepts. Eur J Cardiothorac Surg 2014;45:61-68.

72 Soares JS, Moore JE Jr: Biomechanical challenges to polymeric biodegradable stents. Ann Biomed Eng 2016;44:560-579.

73 Brown BN, Valentin JE, Stewart-Akers AM, McCabe GP, Badylak SF: Macrophage phenotype and remodeling outcomes in response to biologic scaffolds with and without a cellular component. Biomaterials 2009; 30:1482-1491.

74 Gallo M, Bonetti A, Poser H, Naso F, Bottio T, Bianco R, Paolin A, Franci P, Busetto R, Frigo AC, Buratto E, Spina M, Marchini M, Ortolani F, Iop L, Gerosa G: Decellularized aortic conduits: Could their cryopreservation affect post-implantation outcomes? A morphofunctional study on porcine homografts. Heart Vessels 2016; DOI 10.1007/s00380-016-0839-5

75 Brockbank KGM: Effects of cryopreservation upon vein function in vivo. Cryobiology 1994;31:71-81.

76 Song YC, Khirabadi BS, Lightfoot F, Brockbank KGM, Taylor MJ: Vitreous cryopreservation maintains the function of vascular grafts. Nat Biotech 2000;18:296299.

77 Wang S, Goecke T, Meixner C, Haverich A, Hilfiker A, Wolkers WF: Freeze-dried heart valve scaffolds. Tissue Eng Part C Methods 2012;18:517-525.
78 Brockbank KGM: Tissue Engineering Constructs and Commercialization. Austin, Landes Bioscience, 2000.

79 Iso 13485:2016: Medical Devices - Quality Management Systems -Requirements for Regulatory Purposes.

80 Iso 10993-13:2010: Biological Evaluation of Medical Devices - Part 13: Identification and Quantification of Degradation Products from Polymeric Medical Devices.

81 Iso 5840-1:2015: Cardiovascular Implants - Cardiac Valve Prostheses - Part 1: General Requirements.

82 Shinoka T, Ma PX, Shum-Tim D, Breuer CK, Cusick RA, Zund G, Langer R, Vacanti JP, Mayer JE Jr: Tissue-engineered heart valves. Autologous valve leaflet replacement study in a lamb model. Circulation 1996;94(9 suppl):II164-168.

83 Weber B, Scherman J, Emmert MY, Gruenenfelder J, Verbeek R, Bracher M, Black M, Kortsmit J, Franz T, Schoenauer R, Baumgartner L, Brokopp C, Agarkova I, Wolint P, Zund G, Falk V, Zilla P, Hoerstrup SP: Injectable living marrow stromal cell-based autologous tissue engineered heart valves: First experiences with a one-step intervention in primates. Eur Heart J 2011;32: 2830-2840.

84 Baraki H, Tudorache I, Braun M, Hoffler K, Gorler A Lichtenberg A, Bara C, Calistru A, Brandes G, Hewicker-Trautwein M, Hilfiker A, Haverich A, Cebotari S: Orthotopic replacement of the aortic valve with decellularized allograft in a sheep model. Biomaterials 2009;30:6240-6246.

85 Iop L, Bonetti A, Naso F, Rizzo S, Cagnin S, Bianco R, Dal Lin C, Martini P, Poser H, Franci P, Lanfranchi G, Busetto R, Spina M, Basso C, Marchini M, Gandaglia A, Ortolani F, Gerosa G: Decellularized allogeneic heart valves demonstrate self-regeneration potential after a long-term preclinical evaluation. PLoS One 2014;9:e99593.

86 Sievers H-H, Stierle U, Schmidtke C, Bechtel M: Decellularized pulmonary homograft (synergraft) for reconstruction of the right ventricular outflow tract: first clinical experience. Zeitschr Kardiol 2003;92:53-59.

87 da Costa FD, Dohmen PM, Duarte D, von Glenn C, Lopes SV, Filho HH, da Costa MB, Konertz W: Immunological and echocardiographic evaluation of decellularized versus cryopreserved allografts during the ross operation. Eur J Cardiothorac Surg 2005;27:572-578.

88 Zehr KJ, Yagubyan M, Connolly HM, Nelson SM, Schaff HV: Aortic root replacement with a novel decellularized cryopreserved aortic homograft: Postoperative immunoreactivity and early results. J Thor Cardiovasc Surg 2005;130:1010-1015.

89 da Costa FDA, Costa ACBA, Prestes R, Domanski AC, Balbi EM, Ferreira ADA, Lopes SV: The early and midterm function of decellularized aortic valve allografts. Ann Thorac Surg 2010;90:1854-1860.

90 Brown JW, Ruzmetov M, Eltayeb O, Rodefeld MD, Turrentine MW: Performance of synergraft decellularized pulmonary homograft in patients undergoing a ross procedure. Ann Thorac Surg 2011;91:416-423.

91 Konertz W, Dohmen PM, Liu J, Beholz S, Dushe S, Posner S, Lembcke A, Erdbrügger W: Hemodynamic characteristics of the matrix $\mathrm{p}$ decellularized xenograft for pulmonary valve replacement during the ross operation. J Heart Valve Dis 2005;14:78-81.

92 Konertz W, Angeli E, Tarusinov G, Christ T, Kroll J, Dohmen PM, Krogmann O, Franzbach B, Pace Napoleone C, Gargiulo G: Right ventricular outflow tract reconstruction with decellularized porcine xenografts in patients with congenital heart disease. J Heart Valve Dis 2011;20:341-347. 